\title{
Evaluation and comparison of protein composition and quality in half-sib families of opaque-2 maize (Zea mays $\mathrm{L}_{\text {.) }}$ from Argentina
}

\author{
Mansilla, P. S., Nazar, M. C. and Pérez, G. T.
}

\begin{abstract}
SUMMARY
The objective of this study was to characterize and compare the protein composition of half-sib families of opaque-2 maize from Argentina through progeny testing. Grain hardness, protein fractions, amino acid content and in vitro protein digestibility (PD) of whole grain flour were determined. Nonopaque genotypes were used as control. Total protein content of 02 genotypes correlated negatively with the grain hardness ( $r=-42$ in 2012 and $r=-0.32$ in 2013) and did not show significant differences in relation to non-opaque genotypes; however, o2 genotypes showed significantly higher PD, lower zein proportion, and higher albumin, globulin and glutelin contents. The 02 progenies showed significantly higher lysine content and higher levels of other essential amino acids, such as isoleucine and threonine compared to white corn. Lysine content, protein fraction contents and PD showed a higher contribution of genetic variance to the total variability, despite the high contribution of crop year variance obtained by total protein content. The differences shown by progeny protein profiles would enable the identification of 02 genotypes with lower zein level and higher lysine content; this allows us to continue the selection and improvement to obtain open-pollination varieties enhanced in terms of protein quality.
\end{abstract}

Keywords: opaque-2 maize, open-pollinated variety, lysine.

Mansilla, P. S., Nazar, M. C. y Pérez, G. T., 2019. Evaluación y comparación de la composición y calidad proteica de familias de medios hermanos de maíz opaco-2 (Zea mays L.) de Argentina Agriscientia 36: 39-53

\section{RESUMEN}

El objetivo fue caracterizar y comparar la composición proteica de familias de medios hermanos de maíz opaco-2 de Argentina mediante prueba de progenie. Se determinó dureza del grano, contenido de fracciones proteicas, 
aminoácidos y digestibilidad in vitro de proteína (PD) de la harina integral. Se usaron genotipos no-opacos como control. El contenido total de proteína de los genotipos 02 correlacionó negativamente con la dureza del grano ( $r=-42$ en 2012 y $r=-0.32$ en 2013) y no mostró diferencias significativas respecto a los genotipos no-opacos; sin embargo, los genotipos o2 mostraron mayor $\mathrm{PD}$, menor proporción de zeína y mayor de albúminas, globulinas y glutelinas. Las progenies 02 mostraron mayor contenido de lisina, isoleucina y treonina en comparación con el maíz blanco. El contenido de lisina, el de fracciones proteicas y la PD mostraron una mayor contribución de la varianza genética, a pesar de la alta contribución de la varianza del año observada en el contenido total de proteínas. Las diferencias mostradas por los perfiles de proteínas de las progenies permitirán identificar genotipos 02 con menor nivel de zeína y mayor contenido de lisina. Esto permitirá continuar con la selección y la mejora genética para obtener variedades con calidad proteica superior.

Palabras clave: maíz opaco-2, variedad de polinización libre, lisina.

Mansilla, P. S. and Pérez, G. T.: Instituto de Ciencia y Tecnología de Alimentos Córdoba (ICYTAC), CONICET, Ciudad Universitaria, Av. Filloy s/n, 5000 Córdoba, Argentina. Facultad de Ciencias Agropecuarias, Universidad Nacional de Córdoba, CC 509, 5000 Córdoba, Argentina. Nazar, M. C.: Facultad de Ciencias Agropecuarias, Universidad Nacional de Córdoba. Correspondence to: gaperez@agro.unc.edu.ar

\section{INTRODUCTION}

Cereal foods have been the most important sources of dietary energy and nowadays maize is the primary and most important staple (Arendt and Emanuele, 2013). The mature corn kernel is composed of over $70 \%$ of starch. Most of this starch ( 80 to $90 \%$ ) is found in the endosperm, which comprises about $80 \%$ of the total kernel dry weight. Proteins constitute the second most abundant component in the corn kernel after starch, and generally range between 6 and $12 \%$ of the grain dry weight (Serna-Saldivar, 2010). They are distributed mainly in the germ and endosperm and their characteristics differ significantly. The differences between the protein contents in maize can vary markedly according to the genotype, the grain physiological age and the environmental conditions during development and maturation of kernels in the field (Landry, Damerval, Azevedo and Sonia, 2005).

The maize endosperm is composed of an opaque floury region rich in starch, which is located near the center of the kernel, and of another hard vitreous region rich in protein, located near the periphery of the kernel (Hoseney, 1994). In normal maize, the endosperm proteins constitute $80 \%$ of the total grain protein content (Arendt and Emanuele, 2013). In general, the albumins, globulins, prolamins and glutelins account for about $7,5,52$ and $25 \%$ of the whole kernel nitrogen, respectively. The zeins are the main prolamin, and they are deficient in lysine and tryptophan. They are arranged as insoluble aggregates (protein bodies) deposited in the rough endoplasmic reticulum lumen, forming a protein matrix. During the grain maturation, protein bodies are tightly packed between the starch granules in endosperm vitreous regions (Gayral et al., 2016). The different classes of zeins can be distinguished by their different relative mobility on SDSpolyacrylamide gel electrophoresis (SDS-PAGE), by their different solubility and by their different amino acid composition (Rodriguez-Nogales, Garcia and Marina, 2006).

The opaque-2 maize has the recessive mutant gene (02), which encodes a transcription factor (a gene regulator) of zein synthesis (Mertz, Bates and Nelson, 1964). The homozygous o2 mutant causes a decrease of the $\alpha$-zein production, resulting in a redistribution of nitrogen in the endosperm to 
non-zein fractions, as well as the accumulation of free amino acids. Since the non-zein proteins contain higher lysine and tryptophan amount, the effective content of these amino acids of the grain is elevated (Gibbon and Larkins, 2005; Kriz, 2009). The zein synthesis reduction could be related to the low ability of protein bodies to store them (Landry et al., 2005), but it could also result from the cessation of protein synthesis as was suggested by Habben, Kirleis and Larkins (1993). The response of the endosperm containing 02 mutation have been estimated by quantifying their zein or lysine content (Landry et al., 2005).

However, the o2 grains have soft endosperm, and therefore susceptible to pests and fungal diseases, mainly during storage (Vivek, Krivanek, Palacios-Rojas, Twumasi-Afriyie and Diallo, 2008). The progress in the improvement of 02 genotypes with higher lysine contents and endosperm hardness, resulted from the soft grains phenotype suppression by endosperm hardness modifier genes, which convert the soft endosperm to a hard/vitreous endosperm, resulting in the QPM (quality protein maize) varieties (Prasanna, Vasal, Kassahun and Singh, 2001; Sofi, Wani, Rather and Wani, 2009). These modifiers along with the 02 mutant allele can be selected using a method of selection whereby light is projected through the vitreous grains or blocked by the opaque grains respectively (Krivanek, Groote, Gunaratna, Diallo and Friesen, 2007; Vivek et al., 2008). Therefore, in breeding programmes, the selection of genotypes with higher endosperm hardness is essential to reduce the soft phenotype and improve the grain physical traits, resulting in major agronomical acceptance (Krivanek et al., 2007; Gayral et al., 2016).

Multiple genes have been identified as responsible for controlling amino acid content; they affect the relative levels of lysine and tryptophan in the grain endosperm (Wang, Woo, Kim, and Larkins, 2001). Thus, it has become apparent that the simple genetic nature of opaque-2 maize has transformed into a classic polygenic trait and must be manipulated as such in breeding programs. If lysine or tryptophan levels are not continuously measured during the breeding process, the additional gains in protein quality may be lost even though the 0202 genotype is maintained (Krivanek et al., 2007).

Argentina has a great diversity of maize germplasm due to its wide variation in latitude and altitude. The largest grown area in the country is covered by hybrid varieties due to the high heterosis of this species, resulting in a positive rate in the amount of commercial seed obtained per unit area (Rossi, 2007). However, the annual purchase of hybrid seeds represents a high fixed cost, therefore, only producers with substantial economic resources and technologies may remain in the production system. On the other hand, in areas where small farmers do not have economic access to hybrid seeds, the open-pollinated varieties (OPV) prove to be a good choice since producers can keep their own seeds for the following planting season. In addition, the OPV genetic variability allows these varieties to adapt easily to different weather and soil conditions (Kutka, 2011).

Many researchers have suggested that modified ear-to-row method, based on the among-and-within selection of half-sib families, is an effective method of recurrent selection in maize (Acquaah, 2012). In fact, the half-sib selection is based on general combining ability since the entire population serves as a tester for pollination of female plants. The success of the selection is assured by the presence of superior genotypes, which in turn depends on sample size and heritability of selected traits. In maize, this method has been used efficiently for the genetic improvement of high heritability agronomic traits and in the protein and oil content in the kernel (Acquaah, 2012).

Since the discovery of 02 mutation, a lot of studies have been conducted to develop varieties that improve consumers' nutrition, especially in developing countries (Vivek et al., 2008; Gunaratna, Groote, Nestel, Pixley and McCabe, 2010). Currently, opaque-2 and QPM varieties are being disseminated particularly in America and Africa (Krivanek et al., 2007; Gunaratna et al., 2010). In the American continent, the development of cultivars is very widespread in Mexico, Central America and Southern United States and the consumption of opaque-2 and QPM varieties is spread mainly in the form of tortillas and nixtamalized products (RojasMolina et al., 2008). Some studies have focused on the genetic improvement of this germplasm in commercial maize areas from Argentina (Magoja and Nivio, 1982; Magoja, Nivio and Streitenberger, 1984; Corcuera, Salmoral, Kandus, Ferrero and Salerno, 2013; Corcuera, Salmoral, Pennisi, Kandus and Salerno, 2016). The introduction, adaptation, recombination and selection of genotypes would be useful to provide important genetic resources to local producers; at the same time, selected genotypes represent sources of raw material for food production. Therefore, the objective of this study was to characterize and compare the protein composition of half-sib families of opaque-2 maize grown in Argentina in two crop years. 


\section{MATERIALS AND METHODS}

\section{Genetic material}

An opaque-2 maize germplasm provided by International Maize and Wheat Improvement Center (CIMMYT), México, was used as starting material (OP). An adaptation seeding was performed (planting date December 2011) at the experimental field of Facultad de Ciencias Agropecuarias, Universidad Nacional de Córdoba, Argentina (31 $\left.{ }^{\circ} 28^{\prime} 49.42^{\prime \prime} \mathrm{S}, 6^{\circ} 00^{\prime} 36.04^{\prime \prime} \mathrm{W}\right)$. Twelve main cobs of different plants with healthy features were selected (half-sib families) from the original population (OP) and individually harvested (June 2012). After harvest, the cobs were individually threshed, and the opaque grains of each cob were selected using a light table according to Vivek et al. (2008). Approximately 90 opaque kernels of each cob were stored at $4{ }^{\circ} \mathrm{C}$ until planting; the rest were milled in the laboratory to obtain the whole grain flour. In December 2012, the seeds of each cob were planted in individual rows under a randomized complete block design with three replications in order to obtain their individual progenies. The experimental plots were composed of 12 rows (row-family) of $5 \mathrm{~m}$ long, with a spacing of $0.70 \mathrm{~m}$ between rows. In June 2013, the cobs of the best plants within each progeny were harvested (grain moisture at harvest in both years was around $18 \%$ ) and the opaque grains were selected (Vivek et al., 2008). Grains were then stored and milled under the same conditions as those of the 2012 harvest. The field trials in both crop years (December 2011 June 2012 and December 2012 - June 2013) were conducted in the same experimental field (same location) but in different plots uncultivated for a period of three years. The assays were carried out both years under dry conditions without nitrogen fertilization, in order to compare both crops under equal experimental conditions. Table 1 shows the average monthly temperature and precipitation for both crop years.

The opaque grains selected from genotypes harvested in both crop years (twelve half-sib families grown in 2012, and their individual progenies obtained in 2013) were milled in a cyclonic mill (Cyclotec CT193, Foss, Suzhou) without previous drying. Whole grain flour was obtained (moisture around 12 to $15 \%$ and particle size range less than $500 \mu \mathrm{m})$ and stored until chemical analysis. The original population (OP) used as starting material and two non-opaque genotypes (a white corn synthetic variety, WC, and an open-pollinated popcorn variety, PC) were used as controls for comparison.

\section{Physico-chemical composition}

The moisture, protein $(N \times 6.25)$, lipid and ash contents of whole grain flour were determined according to American Association of Cereal Chemists International (AACC International)

Table 1. Average monthly temperatures and total precipitation of crop years

\begin{tabular}{|c|c|c|c|c|}
\hline \multicolumn{5}{|c|}{ Temperature } \\
\hline Crop year month & Minimum $\left({ }^{\circ} \mathrm{C}\right)$ & Maximum $\left({ }^{\circ} \mathrm{C}\right)$ & Average $\left({ }^{\circ} \mathrm{C}\right)$ & $\begin{array}{c}\text { Total } \\
\text { precipitation }(\mathrm{mm})\end{array}$ \\
\hline \multicolumn{5}{|l|}{ 1)2012 } \\
\hline January & $16.2 \mathrm{e}$ & $32.7 e$ & $24.4 f$ & 142.2 \\
\hline February & $17.9 \mathrm{e}$ & $29.6 d$ & $23.8 f$ & 166 \\
\hline March & $13.6 \mathrm{~d}$ & $28.4 d$ & $21.0 \mathrm{e}$ & 54 \\
\hline April & $11.6 \mathrm{~d}$ & $24.4 \mathrm{c}$ & $18.0 \mathrm{~d}$ & 22.2 \\
\hline May & $9.4 \mathrm{c}$ & $23.1 b$ & $16.2 \mathrm{c}$ & 10 \\
\hline June & $3.8 a$ & $19.6 a$ & $11.7 \mathrm{a}$ & 0.8 \\
\hline Average & 12.1 & 26.3 & 19.2 & \\
\hline \multicolumn{5}{|l|}{2013} \\
\hline January & 16.9e & $31.7 e$ & $24.3 f$ & 95.6 \\
\hline February & $15.5 e$ & $28.2 d$ & $21.8 e$ & 90.6 \\
\hline March & $12.6 \mathrm{~d}$ & $25.8 c$ & $19.2 d$ & 44.4 \\
\hline April & $10.2 \mathrm{c}$ & $26.2 d$ & $18.1 \mathrm{~d}$ & 47.4 \\
\hline May & $7.2 \mathrm{~b}$ & $21.9 b$ & $14.5 b$ & 33 \\
\hline June & $4.5 a$ & $20.2 a$ & $12.4 a$ & 2 \\
\hline Average & 11.2 & 25.6 & 18.4 & \\
\hline
\end{tabular}

Values followed by different letters in the same column are significantly different $(P<0.05)$.

1) Grain-filling occurred during April and May in both crop years. 
Approved Methods 44-19.01, 46-13.01, 30-25.01 and 08-01.01, respectively (AACC International, 2010). All determinations were measured at least in duplicate and expressed as $\mathrm{g}_{100 \mathrm{~g}^{-1} \text { of }}$ flour on dry basis (db). Resistant starch (RS) content was determined by enzymatic Resistant Starch assay procedure utilizing commercial K-RSTAR® kit (Megazyme International, Ltd., Bray, Ireland), as described by Mansilla, Nazar and Pérez, 2017. Before such determination, the whole grain flour (100 mg) of each genotype was defatted, suspended in $1.6 \mathrm{~mL}$ of distilled water, and cooked in a boiling water bath for $12.30 \mathrm{~min}$ in order to allow starch gelatinization by simulating a cooking process. Then, samples were incubated with pancreatic $\alpha$-amylase and amyloglucosidase (AMG) in a shaking water bath for $16 \mathrm{~h}$ at $37^{\circ} \mathrm{C}$ to solubilize and hydrolyze non-resistant starch (NRS) to D-glucose by the combined action of the two enzymes. Subsequently, the NRS was separated by centrifugation; the RS-containing pellet was purified with ethanol, solubilized with $2 \mathrm{M} \mathrm{KOH}$, and hydrolyzed to glucose with AMG. Reagent glucose oxidase/peroxidase was used to quantify D-glucose by spectrophotometer at $510 \mathrm{~nm}$. RS plus NRS (digestible starch) was considered total starch content and was expressed as $\mathrm{g}^{100 \mathrm{~g}^{-1} \text { of }}$ flour $(\mathrm{db})$. All determinations were measured at least in duplicate.

Flotation index $(\mathrm{Fl})$ was determined as an indirect measure of grain hardness (Narváez-González et al., 2006). One hundred grains were placed in a beaker containing $500 \mathrm{~mL}$ of $67 \%$ saccharose solution (density of $1.25 \mathrm{~g} \mathrm{~mL}^{-1}$ ). They were stirred and left standing for $1 \mathrm{~min}$. The number of floating grains indicated the flotation index. Hardness classification was based on the scale proposed by Salinas, Bustos and Gomez (1992): FI values between 0 and $12 \%$ are very hard grains, 13 to $37 \%$ are hard grains, 38 to $62 \%$ are intermediate grains, 63 to $87 \%$ are soft and more than $87 \%$ are very soft. All determinations were measured at least in duplicate.

\section{Extraction and quantification of protein fractions}

A sequential extraction procedure of maize protein was carried out following the method described by Malumba, Vanderghem, Deroanne and Béra (2008) with modifications. The albumin fraction ( $A L)$ was twice extracted by stirring defatted flour with distilled water at $4{ }^{\circ} \mathrm{C}$ for $1 \mathrm{~h}$ and centrifuged for $15 \mathrm{~min}$ at $18000 \mathrm{~g}$ (Thermo Scientific, Sorvall ST40R). The meal residues from water-soluble extraction were stirred at room temperature with $0.5 \mathrm{M}$ sodium hydroxide $(\mathrm{NaCl})$ and then centrifuged at $18000 \mathrm{~g}$ for $15 \mathrm{~min}$ to remove globulin fraction (GL). Zein fraction $(Z)$ was solubilized with a $70 \%$ ethanol $+0.5 \%$ sodium acetate solution, and the second zein fraction (Z2) with $70 \%$ ethanol $+0.5 \%$ sodium acetate $+0.6 \%$ Dithiothreitol (DTT). Glutelin G2 fraction was extracted with borate buffer $\mathrm{pH} 10+0.6 \%$ DTT and glutelin G3 fraction with borate buffer $\mathrm{pH} 10+0.6 \%$ DTT $+0.5 \%$ of sodium dodecyl sulfate (SDS). The protein content of each fraction $(N \times 6.25)$ was determined by the micro-Kjeldalh method modified to boric acid (AACC International, 2010). All determinations were measured at least in duplicate and the extracts were stored at $-18{ }^{\circ} \mathrm{C}$. The results were expressed as protein percentage of each fraction from the flour ( $g$ protein fraction $100 \mathrm{~g}^{-1}$ of flour) (db).

\section{Electrophoresis}

Electrophoresis was performed in polyacrylamide SDS gels (SDS-PAGE). The protein extracts were precipitated with acetone (1:3) and reduced by heating at $95{ }^{\circ} \mathrm{C}$ for $5 \mathrm{~min}$ in a sample buffer containing $0.063 \mathrm{M} \mathrm{Tris} / \mathrm{HCl} \mathrm{pH} 6.8,2 \%$ of SDS $\mathrm{p} / \mathrm{v}, 10 \%$ of glycerol $\mathrm{v} / \mathrm{v}, 5 \%$ of $\beta$ - mercaptoethanol and $0.05 \%$ of bromophenol blue $\mathrm{p} / \mathrm{v}$ (Duodu et al., 2002). The separating gel concentrations were $12 \%$ acrylamide for albumin, globulin and glutelin fractions, and $15 \%$ acrylamide for the zein fraction. Runs were stopped when the running front reached the end of the gel, and then stained using Coomassie blue. A Bio-Rad SDS-PAGE Standards, Broad Range (200 to $6.5 \mathrm{kDa}$ ) marker was used to determine the molecular weights of the polypeptide bands of the extracts.

\section{Amino acid content}

Samples of whole grain flour (1 g, db) were hydrolyzed with $50 \mathrm{~mL}$ of hydrochloric acid $(\mathrm{HCl})$ $6 \mathrm{M}$ and were heated in reflux in a heating mantle for $24 \mathrm{~h}$, according to AOAC International (1999) Method 994.13. The derivatization was performed according to the method described by Alaiz, Navarro, Girón and Vioque (1992). Amino acids were determined with an HPLC Perkin Elmer, Serie 200 equipment with an UV-visible detector (280 nm), using a Zorbax Eclipse Plus C18 (4.6 x $150 \mathrm{~mm}$ ) column, and a particle size $5 \mu \mathrm{m}$ (Agilent Technologies). The amino acid content

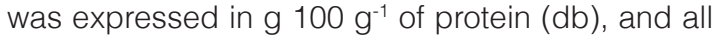
determinations were measured in quadruplicate. 


\section{In vitro protein digestibility}

In vitro protein digestibility was determined according to the procedure described by Hamaker, Kirleis, Butler, Axtell and Mertz (1987), with modifications. Samples of whole grain flour (200 mg, db) of each genotype were suspended in $2 \mathrm{~mL}$ of distilled water and cooked in a boiling water bath for $10 \mathrm{~min}$, in order to simulate a cooking process (Duodu et al., 2002). Then, samples were cooled at room temperature and centrifuged during $10 \mathrm{~min}$ at $4000 \mathrm{~g}$. The residues were suspended in phosphate buffer $0.1 \mathrm{M} \mathrm{pH} 2$ with pepsin (Sigma P-7000-25G, activity $683 \mathrm{U} \mathrm{mg}^{-1}$ of protein) and incubated in a shaking water bath at $37^{\circ} \mathrm{C}$. Pepsin digestion was stopped at $2 \mathrm{~h}$ with the addition of $2 \mathrm{~mL}$ of $2 \mathrm{M} \mathrm{NaOH}$. An aliquot (1.5 $\mathrm{mL}$ ) was centrifuged at $14000 \mathrm{~g}$ for $10 \mathrm{~min}$ at 25 ${ }^{\circ} \mathrm{C}$ and the solubilized protein in the supernatant was determined by Lowry method (Waterborg, 2002). The absorbances were measured in a spectrophotometer (UV-visible JascoV-730, Jasco Corporation, Japan) at $550 \mathrm{~nm}$ and a calibration pattern with bovine serum albumin (Sigma A2153$10 G$, lyophilized powder >96 \%) was used as standard, at concentrations from 0.01 to $2 \mathrm{mg} \mathrm{mL}^{-1}$. The percentage of digested protein with respect to the total protein content was considered as in vitro digestibility. All determinations were measured at least in duplicate.

\section{Statistical analysis}

Statistical analyses were performed using Infostat/Professional statistical software (Di Rienzo et al., 2018). The data were examined by ANOVA and Di Rienzo, Guzmán and Casanoves's multiple comparison test (DGC) (Di Rienzo, Guzmán and Casanoves, 2002) was applied. The differences between genotypes (average of each genotype from the two harvests, 2012 and 2013) and crop years (average of all genotypes from each year, 2012 or 2013) were analyzed. In addition, the individual progenies were compared with the original population used as starting material and with two non-opaque genotypes (white corn and popcorn) used as controls.

The variance components were estimated by Linear Mixed Models (MLM) through Restricted Maximum-Likelihood estimator (REML). The genotype factor (progenies) was taken nested within the environment factor (crop year), both as random effects, and the residual variance was considered as the interaction between both factors (Di Rienzo, Macchiavelli and Casanoves, 2017). In this way, it was possible to assess the relative magnitude of the genetic variance (given by the genetic differences between genotypes) of environment (given by crop year) and of the genotype $x$ year interaction (given by residual variance), determined as percentage of the contribution to the total variance. Non-opaque controls were not included in the analysis. The relationships between parameters were determined by Pearson's correlation test (significant level at $P<0.05)$.

\section{RESULTS AND DISCUSSION}

\section{Grain composition}

The opaque-2 genotypes showed significant differences between total starch and protein content, but the average values did not show significant differences when compared with white corn and popcorn (Table 2). These results have already been discussed in a previous research focused on starch properties of these opaque-2 genotypes (Mansilla et al., 2017). On the other hand, Ortiz-Martinez, Otero-Pappatheodorou, Serna-Saldívar and García-Lara (2017) obtained significantly higher protein content in QPM corn $(13.5 \%)$ in relation to normal corn $(9.25 \%)$; these differences were attributed to the contribution of the germ protein. Cázares-Sánchez, ChávezServia, Salinas-Moreno, Castillo-González and Ramírez-Vallejo (2015) reported a similar protein range when they analyzed 41 populations of Mexican native corns (9.35 - $12.50 \%$ ) with different types of endosperm. The opaque-2 progenies showed higher FI than non-opaque controls (Table 2 ), indicating that opaque-2 maize had very soft grains compared with intermediate and very hard grains of white corn and popcorn, respectively. Opaque-2 maize contains a higher proportion of floury endosperm, with a dull appearance due to the loose packing of starch granules (Gibbon and Larkins, 2005). Similar results were demonstrated by Narváez-González et al. (2006) in grain hardness of maize races from México. Previous reports (Joshi, Lodha and Mehta, 1980) stated that opaque-2 maize endosperm has a lower starch amount than normal maize, as reported by OrtizMartinez et al. (2017) who obtained a significantly lower starch content in a QPM variety $(64.14 \%)$ in relation to normal corn (73.26 \%). However, Pereira et al. (2008) demonstrated that the highest total starch levels were both in genotypes with hard and soft endosperm, so they rejected an association between starch content and endosperm hardness, in agreement with the present study. 
Table 2. Grain hardness, flour chemical composition and in vitro protein digestibility of maize genotypes

\begin{tabular}{|c|c|c|c|c|c|c|c|c|}
\hline \multirow{3}{*}{ 1) Genotype } & \multirow{3}{*}{$\begin{array}{l}\text { Flotation } \\
\text { Index (\%) }\end{array}$} & \multicolumn{4}{|c|}{ Centesimal composition (g $100^{-1} \mathrm{~g}$ of flour) } & \multicolumn{2}{|c|}{$\begin{array}{c}\text { Protein composition } \\
\left(\mathrm{g} 100^{-1} \mathrm{~g} \text { of flour }\right)\end{array}$} & \multirow[t]{3}{*}{ PD (\%) } \\
\hline & & \multirow{2}{*}{ Starch } & \multirow{2}{*}{ Lipid } & \multirow{2}{*}{ Ash } & \multirow{2}{*}{ Protein } & Zeins & Non-zeins & \\
\hline & & & & & & 2) $Z+Z 2$ & $A L+G B \quad G 2+G 3$ & \\
\hline P 3 & $91.8 \pm 3.7 c$ & $61.9 \pm 3.4 a$ & $10.9 \pm 0.9 d$ & $1.9 \pm 0.2 b$ & $11.6 \pm 0.5 d$ & $3.7 \pm 0.6 f$ & $3.4 \pm 0.2 b 2.8 \pm 0.4 a$ & $74.9 \pm 1.7 b$ \\
\hline P 5 & $86.5 \pm 2.8 b$ & $65.5 \pm 1.3 b$ & $7.7 \pm 1.3 b$ & $1.7 \pm 0.1 \mathrm{a}$ & $11.3 \pm 0.4 \mathrm{c}$ & $2.2 \pm 0.1 c$ & $3.3 \pm 0.2 b 3.2 \pm 0.1 b$ & $59.1 \pm 5.8 a$ \\
\hline P 10 & $97.8 \pm 4.2 d$ & $63.6 \pm 1.1 b$ & $8.5 \pm 0.56 c$ & $1.8 \pm 0.2 a$ & $11.0 \pm 0.2 \mathrm{c}$ & $2.2 \pm 0.2 c$ & $2.9 \pm 0.3 a 3.8 \pm 0.7 d$ & $68.5 \pm 8.6 b$ \\
\hline P 13 & $84.8 \pm 2.2 b$ & $66.3 \pm 2.3 b$ & $7.9 \pm 2.6 b$ & $1.9 \pm 0.1 b$ & $10.1 \pm 0.7 a$ & $2.2 \pm 0.4 \mathrm{c}$ & $4.2 \pm 0.6 \mathrm{~d} 4.4 \pm 0.2 \mathrm{e}$ & $\pm 2.7 \mathrm{~b}$ \\
\hline P 15 & $96.0 \pm 2.9 d$ & $63.3 \pm 3.1 b$ & $8.7 \pm 0.6 c$ & $2.0 \pm 0.0 \mathrm{c}$ & $10.1 \pm 0.9 a$ & $1.7 \pm 0.1 \mathrm{a}$ & $3.6 \pm 0.5 c 3.2 \pm 0.1 b$ & $67.7 \pm 8.9 b$ \\
\hline P 18 & $97.0 \pm 5.7 d$ & $64.5 \pm 2.8 b$ & $8.8 \pm 2.3 c$ & $1.9 \pm 0.1 b$ & $9.8 \pm 1.7 \mathrm{a}$ & $2.1 \pm 0.3 b$ & $3.8 \pm 0.2 c 3.5 \pm 0.2 c$ & $\pm 3.0 \mathrm{c}$ \\
\hline P 19 & $94.5 \pm 7.1 \mathrm{c}$ & $60.9 \pm 1.0 a$ & $8.1 \pm 0.4 b$ & $1.9 \pm 0.1 b$ & $11.1 \pm 0.9 c$ & $2.4 \pm 0.5 c$ & $4.4 \pm 0.7$ e $3.4 \pm 0.3 c$ & $70.4 \pm 7.3 b$ \\
\hline P 20 & $88.5 \pm 3.7 b$ & $65.2 \pm 1.3 b$ & & & & $2.3 \pm 0.1 \mathrm{c}$ & $3.4 \pm 0.1 b 2.9 \pm 0.1 a$ & $89.1 \pm 8.0 \mathrm{c}$ \\
\hline P 22 & $98.5 \pm 5.5 d$ & $65.7 \pm 2.1 b$ & $9.1 \pm 0.8 \mathrm{c}$ & $2.1 \pm 0.1 d$ & $10.4 \pm 0.6 b$ & $1.6 \pm 0.2 a$ & $4.1 \pm 0.4 d 3.5 \pm 0.2 c$ & $\pm 6.4 \mathrm{C}$ \\
\hline P 25 & $92.0 \pm 1.9 c$ & $63.5 \pm 1.3 b$ & $6.7 \pm 0.8 a$ & $2.0 \pm 0.1 \mathrm{c}$ & $11.9 \pm 0.7 d$ & $2.2 \pm 0.1 \mathrm{c}$ & $4.1 \pm 0.4 d 3.5 \pm 0.4 c$ & $84.6 \pm 2.0 \mathrm{c}$ \\
\hline P 26 & $86.0 \pm 4.9 b$ & $61.8 \pm 2.2 \mathrm{a}$ & $7.7 \pm 1.5 b$ & $1.9 \pm 0.2 b$ & $10.5 \pm 0.8 b$ & $2.7 \pm 0.2 \mathrm{e}$ & $3.6 \pm 0.4 c 3.4 \pm 0.3 c$ & $61.9 \pm 7.6 a$ \\
\hline P 28 & $81.3 \pm 1.2 \mathrm{a}$ & $66.0 \pm 4.5 b$ & $8.0 \pm 1.4 b$ & $2.1 \pm 0.2 d$ & $12.3 \pm 0.8 \mathrm{e}$ & $2.5 \pm 0.4 d$ & $4.1 \pm 0.1 d 3.2 \pm 0.2 b$ & $80.1 \pm 6.7 \mathrm{c}$ \\
\hline $\mathrm{OP}$ & $98.7 \pm 8.1 d$ & $61.2 \pm 1.3 a$ & $8.6 \pm 0.1 \mathrm{c}$ & $2.1 \pm 0.1 d$ & $10.6 \pm 0.3 b$ & $2.1 \pm 0.1 b$ & $3.4 \pm 0.0 b 3.3 \pm 0.1 \mathrm{c}$ & $85.3 \pm 7.0 \mathrm{c}$ \\
\hline \multicolumn{9}{|l|}{ 3) Year } \\
\hline 2012 & $94.6 \pm 9.1 b$ & $65.0 \pm 3.9 b$ & $8.2 \pm 1.6 a$ & $1.9 \pm 0.2 a$ & $10.3 \pm 0.9 a$ & $2.2 \pm 0.7 a$ & $3.9 \pm 0.6 b 3.4 \pm 0.5 a$ & $74.1 \pm 9.7 a$ \\
\hline 2013 & $89.2 \pm 8.50 a$ & $62.6 \pm 2.7 a$ & $8.6 \pm 1.4 b$ & $2.0 \pm 0.3 b$ & $11.4 \pm 0.8 b$ & $2.4 \pm 0.4 b$ & $3.6 \pm 0.6 a 3.4 \pm 0.4 a$ & $78.9 \pm 8.9 b$ \\
\hline \multicolumn{9}{|l|}{ 4) Comparison } \\
\hline Opaque & $91.9 \pm 7.2 \mathrm{c}$ & $63.8 \pm 3.5 a$ & $8.4 \pm 1.5 b$ & $1.9 \pm 0.2 b$ & $10.8 \pm 1.1 \mathrm{a}$ & $2.3 \pm 0.6 a$ & $3.7 \pm 0.6 b 3.4 \pm 0.5 b$ & $76.5 \pm 11.8 b$ \\
\hline WC & $62.0 \pm 2.1 b$ & $66.3 \pm 1.3 a$ & $6.7 \pm 0.9 a$ & $1.7 \pm 0.1 \mathrm{a}$ & $11.2 \pm 0.6 a$ & $4.9 \pm 0.0 b$ & $2.0 \pm 0.1 \mathrm{a} 2.4 \pm 0.1 \mathrm{a}$ & $70.0 \pm 1.8 \mathrm{a}$ \\
\hline $\mathrm{PC}$ & $12.0 \pm 3.2 \mathrm{a}$ & $66.2 \pm 0.8 a$ & $7.8 \pm 0.4 a$ & $1.5 \pm 0.0 a$ & $10.3 \pm 0.4 a$ & $4.7 \pm 0.1 b$ & $2.0 \pm 0.0 a 2.9 \pm 0.0 a$ & $67.6 \pm 1.5 a$ \\
\hline
\end{tabular}

Values followed by different letters in the same column are significantly different $(P<0.05)$.

${ }^{1)}$ Values of each genotype ( $P$ followed by a number) and Original Population $(\mathrm{OP})$ correspond to the average between both crop years (2012 and 2013). Parameters expressed and compared on dry basis.

2) $Z+Z 2$ = zeins; $A L+G B=$ albumins + globulins; $G 2+G 3$ = glutelins; $P D=$ in vitro protein digestibility.

${ }^{3)}$ Comparison of annual averages of all opaque-2 half-sib families harvested in 2012 and their individual progenies grown in 2013. The data shown for 2012 correspond to the average of the twelve opaque-2 half-sib families harvested in that year. Data shown for 2013 correspond to the average of their twelve individual progenies grown in 2013 , in order to compare annual average variation on analyzed genotypes.

${ }^{4)}$ Comparison of the average between all opaque-2 genotypes (Opaque) in both crop years with white corn (WC) and popcorn (PC) used as controls.

Significant differences were obtained in lipid and ash contents of opaque-2 genotypes, whose average values were higher than those obtained in white corn and popcorn used as controls (Table 2), as described in a previous work (Mansilla et al., 2017). Lower lipid and ash contents were reported by Corcuera et al. (2013) and Mendoza-Elos et al. (2006) in experimental hybrids. On the other hand, Cázares-Sanchez et al. (2015) reported lower lipid levels in 41 native populations of Mexican maize. No significant correlations were obtained between lipids with protein, starch and ash contents in any crop year, in agreement with other studies (Cázares-Sanchez et al., 2015).

An annual increase in protein content and a decrease in starch content were observed in opaque-2 genotypes (Table 2). The lower amount of starch in corn endosperm results in an increase in protein content (Serna-Saldivar, 2010), which was coincident with a negative correlation between protein and starch in both crop years ( $r=-0.43$ in 2012 and $r=-0.51$ in 2013; $P<0.05$ ) within 02 genotypes. Several research studies proved that prevailing high temperatures during grain filling cause an increase in protein content and a decrease in starch, inducing changes in physicochemical properties (Beckles and Thitisaksakul, 2014). On the other hand, other works showed an increase in protein contents of experimental and commercial hybrids grown under drought conditions in relation to those cultivated under well-watered environments (Scott, Edwards, Bell, Schussler and Smith, 2006). The environmental effect is greater in the beginning of grain filling due to the interference of physiological 
and biochemical cellular processes, and to an alteration of enzymatic activity (Thitisaksakul, Jiménez, Arias and Beckles, 2012). In the present study, there was a significant increase in the average maximum temperature of April 2013 in relation to 2012, month during which the grain filling took place (Table 1). However, the rainfall recorded in the same period was higher in 2013 , which does not suggest water stress conditions during grain development. This would indicate that mainly high temperatures could have influenced the biosynthesis of grain components and could have translated into the annual variations observed in the progenies in 2013 (Table 2).

On the other hand, the protein of maize grain can be modified by soil nitrogen level, as demonstrated in other studies. The variations in nitrogen levels have a direct relationship with the protein/starch ratio of kernels (Ngaboyisonga, Njoroge, Kirubi and Githiri, 2008). In this study, nitrogen fertilization was not performed in any crop cycle, and experimental conditions in both years were similar.

\section{Protein composition}

Maize protein fractions were quantified and grouped as zeins and non-zeins (albumins + globulins and glutelins). Significant differences were obtained between opaque-2 genotypes (Table 2). Landry, Delhaye and Damerval (2004) reported similar glutelin (3.48 \%), higher zein (6.85 $\%)$ and lower albumin + globulin $(0.65 \%)$ contents in inbred lines of floury maize in relation to those shown by 02 genotypes of this study (Table 2). The decrease in zein synthesis of 02 mutant genotypes could be related to a low storage capacity of endosperm protein bodies. This promotes the non-zein synthesis as a compensatory effect (Landry et al., 2005), resulting in higher albumin, globulin and glutelin contents in the mature kernel. Ortiz-Martinez et al. (2017) reported albumin and globulin contents in QPM varieties similar to those obtained in 02 genotypes of this study (Table 2). The synthesis and accumulation of albumins and globulins decline rapidly during grain maturation of normal endosperm genotypes in relation to 02 and QPM genotypes. However, the final albumin + globulin contents in mature grain of these genotypes are twice as much as in normal endosperm corns (Wall and Bietz, 1987; Ortiz-Martinez et al., 2017).

The P3 progeny showed significantly higher zein content and lower glutelin content than the rest of the genotypes (Table 2). This sample also had one of the highest total protein contents (Table 2). The zein synthesis shows a linear relationship based on total protein content regardless of environment conditions (Landry et al., 2005). Conversely, the P15 and P22 progenies showed a significantly lower zein content. In addition, progeny P22 was located between the samples with higher albumin + globulin and glutelin contents than the rest of the genotypes and in relation to the original population (OP) (Table 2). This indicates differences in protein composition with the starting genetic material.

When the protein fraction distribution was analyzed in relation to the total protein content, the average value of zein proportion within opaque-2 genotypes $(21.09 \%)$ was lower than that of albumins + globulins (34.64\%) and glutelins (31.83 $\%)$, and significantly lower than the zein proportion of popcorn $(45.71 \%)$ and white corn $(43.46 \%)$. In the same way, the proportion of albumins + globulins and glutelins of white corn (18\% and $21 \%$, respectively) and popcorn (19.55\% and $28.27 \%$, respectively) were significantly lower than 02 genotypes. Similar results were reported by Yau, Bockholt, Smith, Rooney and Waniska (1999) in MO17 experimental inbred line, where zein proportions in their 02 and QPM homologous versions were significantly lower than their normal counterparts and they did not show differences in total protein content. The 02 mutation in homozygous state modifies the corn protein quality but does not change the total protein content of the kernel (Gibbon and Larkins, 2005; Vivek et al., 2008). Malumba et al. (2008) reported similar results in flint corn to those obtained in white corn and popcorn in the present study.

The zein fraction showed a negative correlation with glutelin ( $r=-0.71$ in 2012 and $r=-0.41$ in 2013; $P<0.05)$ and albumin + globulin fractions ( $r=-$ 0.69 in 2012 and $r=-0.74$ in 2013; $P<0.05)$ within opaque-2 genotypes. In addition, the albumins correlated positively with globulins ( $r=0.53$ in 2012 and $r=0.47$ in 2013; $P<0.05)$. These results are coincident with other research studies in which the protein composition variations of 02 mutants in relation to normal genotypes were attributed mainly to a decrease in zein fractions (Gibbon and Larkins, 2005; Ortiz-Martinez et al., 2017). On the other hand, FI correlated negatively with protein $(r=-42$ in 2012 and $r=-0.32$ in 2013; $P<0.05)$ and zein $(r=-$ 0.38 in 2012 and $r=-0.35$ in 2013, $P<0.05$ ) contents within 02 progenies, in agreement with other studies (Narváez-González et al., 2006). The zeins are closely related to endosperm hardness because they allow the association between starch granules with the protein matrix (Dombrink-Kurtzman and Bietz, 1993). Despite the opaque-2 genotypes have very soft grains, $\mathrm{P} 13$ and $\mathrm{P} 28$ showed lower FI and high albumin + globulin and glutelin fractions 
(Table 2), being essential to identifying progenies with high non-zein fractions and better physical features such as grain hardness.

When the variations between crop years in opaque-2 genotypes were compared, the average annual increase in total protein content was accompanied by an increase in zein fraction content and a decrease in FI (Table 2). Concomitantly, a positive correlation between protein and zeins was observed in both crop years $(r=0.45$ in 2012 and $r=0.37$ in 2013; $P<0.05$ ). The albumin + globulin fractions showed a decrease from one year to another (Table 2). However, the glutelin fraction did not show a significant annual variation despite the positive correlation obtained with albumins + globulins ( $r=0.42$ in 2012 and $r=0.54$ in 2013; $P<0.05)$. These relationships were similar to those reported by Yau et al. (1999).

\section{In vitro protein digestibility}

The opaque-2 genotypes showed significant differences in protein digestibility in cooked flour, whose average value was higher than white corn and popcorn (Table 2). Duodu et al. (2002) indicated that a tighter packaging degree of starch granules in the protein matrix of vitreous endosperm may affect the accessibility of digestive enzymes to flour particles. In this study, the higher vitreous endosperm proportion of popcorn and white corn would probably explain the lower protein digestibility obtained with respect to 02 genotypes. The P22 progeny showed the highest value, although it did not differ significantly from the P18, P20, P25, P28 and OP samples (Table 2). Lower in vitro protein digestibility values were obtained by Duodu et al. (2002) in cooked and uncooked white corn flours and whole grain corn flours subjected to pepsin digestion (from 62 to $68 \%$ ).

Some previous studies reported significant reductions in protein digestibility from sorghum whole grain flours after cooking. However, corn flours showed higher digestibility compared to sorghum (Hamaker, Kirleis, Mertz and Axtell, 1986; Duodu et al., 2002). In sorghum and maize, the cooking process leads to the formation of oligomeric proteins linked by disulfide bridges that surround monomeric prolamines. These protein structures depend on prolamin composition and conformation of each cereal and they are weaker in corn than in sorghum (Hamaker et al., 1986). This may result in less resistance to enzymatic action, which probably causes higher corn protein digestibility (Duodu et al., 2002). In this study, the endosperm zein content of maize genotypes probably represented one of the main structural factors of grains that influenced the protein digestibility after cooking, as was observed in the negative correlation between zeins and protein digestibility obtained in the 2013 progenies $(r=-0.40 ; P<0.05)$. In addition, a joint increase from one crop year to another was observed in protein digestibility and in the zein content of opaque-2 genotypes (Table 2), which could be related to the increase in total protein content in 2013, indicating a higher amount of substrate for protein digestion.

\section{Electrophoresis of protein fractions}

An electrophoresis of each extract was performed in polyacrylamide gels (SDS-PAGE). Within opaque-2 genotypes, zein fraction showed a similar band pattern in both crop years and molecular weights ranged from 6.5 to $45 \mathrm{kDa}$ (Figure 1). Albumin (from 21 to $97 \mathrm{kDa}$ ), globulin

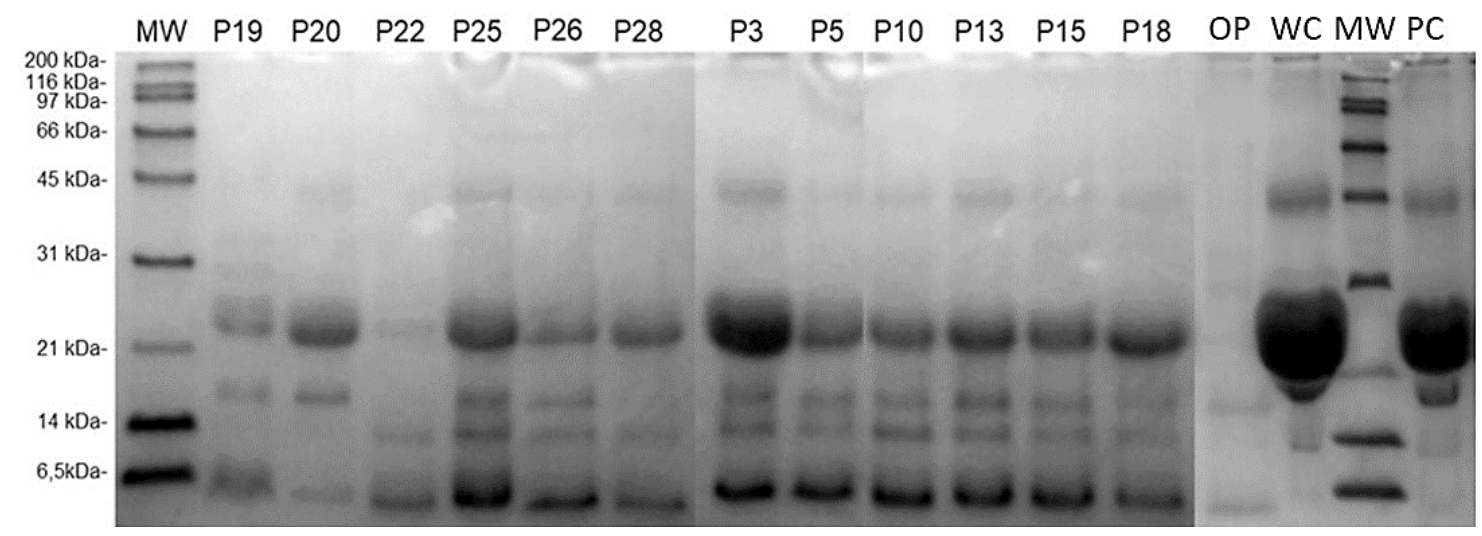

Figure 1. SDS electrophoretic comparison of zeins from whole endosperm of the maize genotypes. The lanes represent the half-sib families of opaque-2 maize selected in 2012 (P followed by a number), the original population (OP), the white corn (WC) and popcorn (PC) used as controls. MW, molecular weight marker. 
(from 14 to $66 \mathrm{kDa}$ ) and glutelin (from 21 to 66 $\mathrm{kDa}$ ) patterns did not show great differences in the intensity of the bands between genotypes (data not shown). Landry et al. (2004) reported a range from 14 to $22 \mathrm{kDa}$ in zein protein extracts of vitreous and floury corn endosperm. The P3 sample showed the highest intensity of the bands between 21-31 $\mathrm{kDa}$ and $45 \mathrm{kDa}$ in 2012 with respect to the other opaque-2 samples (Figure 1), which was consistent with the highest zein content shown by that sample in both crop years (Table 2). Conversely, the lowest zein content of P22 in both crop years (Table 2) was coincident with the lower band pattern intensity shown by this sample in 2012, in relation to the other o2 genotypes (Figure 1).

When comparing electrophoretic patterns of non-opaque controls with opaque-2 genotypes, a marked increase was observed in the intensity of 21$31 \mathrm{kDa}$ and $45 \mathrm{kDa}$ molecular mass bands in white corn and popcorn (Figure 1). This was reflected on the significantly higher zein content shown by these samples with respect to 02 genotypes (Table 2). Some studies showed that the hard endosperm region of the corn kernel has higher $\alpha$-zein (22 and $19 \mathrm{kDa}$ ) and $\gamma$-zein (27 and $16 \mathrm{kDa}$ ) contents and that the $27 \mathrm{kDa} \gamma$-zein determines the vitreous endosperm formation (Dombrink-Kurtzman and Bietz, 1993). However, in this electrophoretic study, a single broad band comprised between 22 and 30 $\mathrm{kDa}$ was observed and it could not be seen as two distinct bands due to the high zein concentration and the similar molecular mass of the zein bands. Malumba et al. (2008) reported a similar zein electrophoretic pattern in flint corn genotype, where the molecular mass bands between 20 and $30 \mathrm{kDa}$ showed higher intensity. On the other hand, Pereira et al. (2008) demonstrated a decrease in 22 and 19 $\mathrm{kDa}$ zein band intensity of 02 mutant genotype with respect to QPM and hard endosperm samples. However, other studies indicated that there is no clear relationship between the appearance of $27 \mathrm{kDa} \gamma$-zein and vitreous endosperm in maize (Landry et al., 2004; Gibbon and Larkins, 2005).

\section{Amino acid analysis}

Based on protein fraction contents and their electrophoretic patterns, the amino acid profile was determined: in opaque-2 genotypes that showed the highest zein content in both crop years (P3) (Table 2), in those that presented the lowest zein levels (P15 and P22) (Table 2), in the original population (OP), and in the white corn (WC) used as non-opaque control for comparison. Significant differences were obtained in the amino acid profiles among analyzed genotypes and the lysine contents of 02 progenies were significantly higher than white corn (Table 3). Considerably lower lysine contents than opaque-2 genotypes and similar to the white corn used as control in the present study were reported in native populations of Mexican corns by Cázares-Sanchez et al. (2015) and Vera-Guzmán, Chávez-Servia and CarrilloRodríguez (2012) (0.27 - 0.39 and 0.4 - 0.6 g 100 $\mathrm{g}^{-1}$ of protein, respectively). However, other studies reported higher lysine contents in hybrids, and 02 and QPM lines (Wall and Paulis, 1978; Magoja et al., 1984; Sofi et al., 2009; Corcuera et al., 2016).

Table 3. Amino acid content (g $100^{-1} \mathrm{~g}$ of protein) of maize genotypes

\begin{tabular}{lcccccc}
\hline & ${ }^{1)} \mathrm{P} \mathrm{3}$ & $\mathrm{P} \mathrm{15}$ & $\mathrm{P} \mathrm{22}$ & $\mathrm{OP}$ & Opaque average & WC \\
\hline Aspartic Acid & $3.96 \pm 0.20 \mathrm{c}$ & $6.35 \pm 0.58 \mathrm{e}$ & $5.68 \pm 0.80 \mathrm{~d}$ & $3.02 \pm 0.34 \mathrm{~b}$ & $4.92 \pm 1.42$ & $1.91 \pm 0.01 \mathrm{a}$ \\
Glutamic Acid & $6.41 \pm 1.69 \mathrm{c}$ & $6.45 \pm 1.31 \mathrm{~d}$ & $2.71 \pm 0.36 \mathrm{a}$ & $4.26 \pm 0.87 \mathrm{~b}$ & $5.06 \pm 1.37$ & $3.94 \pm 0.03 \mathrm{~b}$ \\
Glycine & $0.52 \pm 0.12 \mathrm{~b}$ & $1.42 \pm 0.48 \mathrm{c}$ & $0.83 \pm 0.08 \mathrm{~b}$ & $0.57 \pm 0.12 \mathrm{~b}$ & $0.86 \pm 0.39$ & $0.09 \pm 0.01 \mathrm{a}$ \\
Threonine & $0.87 \pm 0.02 \mathrm{a}$ & $1.85 \pm 0.26 \mathrm{~b}$ & $2.20 \pm 0.20 \mathrm{~b}$ & $0.70 \pm 0.13 \mathrm{a}$ & $1.50 \pm 0.86$ & $0.31 \pm 0.00 \mathrm{a}$ \\
Arginine & $5.34 \pm 0.03 \mathrm{a}$ & $5.03 \pm 1.23 \mathrm{a}$ & $7.12 \pm 1.83 \mathrm{~b}$ & $4.96 \pm 0.64 \mathrm{a}$ & $5.62 \pm 2.03$ & $2.34 \pm 0.00 \mathrm{a}$ \\
Alanine & $6.97 \pm 1.29 \mathrm{c}$ & $5.48 \pm 0.62 \mathrm{~b}$ & $4.19 \pm 0.89 \mathrm{a}$ & $5.47 \pm 0.20 \mathrm{~b}$ & $5.43 \pm 1.46$ & $6.02 \pm 0.03 \mathrm{~b}$ \\
Proline & $2.93 \pm 0.19 \mathrm{a}$ & $2.63 \pm 0.32 \mathrm{a}$ & $6.92 \pm 1.05 \mathrm{~b}$ & $4.77 \pm 1.42 \mathrm{~b}$ & $4.40 \pm 2.13$ & $5.10 \pm 0.28 \mathrm{~b}$ \\
Tyrosine & $2.30 \pm 0.94 \mathrm{c}$ & $1.80 \pm 0.22 \mathrm{~b}$ & $1.45 \pm 0.56 \mathrm{~b}$ & $1.05 \pm 0.56 \mathrm{a}$ & $1.58 \pm 0.73$ & $1.70 \pm 0.15 \mathrm{~b}$ \\
Isoleucine & $2.58 \pm 0.44 \mathrm{a}$ & $3.18 \pm 0.59 \mathrm{a}$ & $2.21 \pm 0.38 \mathrm{a}$ & $2.33 \pm 0.04 \mathrm{a}$ & $2.58 \pm 0.60$ & $1.95 \pm 0.00 \mathrm{a}$ \\
Leucine & $7.35 \pm 1.91 \mathrm{c}$ & $5.48 \pm 1.55 \mathrm{~b}$ & $5.66 \pm 0.58 \mathrm{~b}$ & $4.93 \pm 0.08 \mathrm{a}$ & $5.86 \pm 1.48$ & $7.04 \pm 0.03 \mathrm{c}$ \\
Phenylalanine & $3.62 \pm 0.97 \mathrm{c}$ & $3.36 \pm 0.83 \mathrm{~b}$ & $3.19 \pm 0.51 \mathrm{~b}$ & $2.16 \pm 0.02 \mathrm{a}$ & $3.08 \pm 0.82$ & $3.04 \pm 0.02 \mathrm{~b}$ \\
Lysine & $0.66 \pm 0.04 \mathrm{~b}$ & $1.5 \pm 0.05 \mathrm{~d}$ & $1.25 \pm 0.07 \mathrm{c}$ & $0.65 \pm 0.03 \mathrm{~b}$ & $1.00 \pm 0.39$ & $0.21 \pm 0.01 \mathrm{a}$ \\
\hline Values followed by different letters in the same row are significantly different $(\mathrm{P}<0.05)$. & &
\end{tabular}

1) Values of each genotype (P3, P15 and P22) correspond to the average between both crop years (2012 and 2013) and were compared with the original population (OP) and with white corn (WC) used as control. Parameters expressed and compared on dry basis. 
The joint increase of certain essential amino acids in opaque-2 corn is the product of the combination of biochemical events, such as a higher synthesis and a lower catalysis of these amino acids, an increase in the synthesis and the accumulation of soluble proteins and a decrease in the zein synthesis (Jia et al., 2013). These factors also produce changes in other amino acid content of the kernel. The opaque-2 genotypes showed higher isoleucine, phenylananine and threonine average contents with respect to white corn used as control in this study (Table 3). Several research studies have reported higher levels of methionine, cysteine, histidine, isoleucine, leucine, phenylananine, tyrosine, threonine and valine in whole grains of 02 and QPM varieties, in relation to normal maize (Ortiz-Martinez et al., 2017).

On the other hand, the contents of arginine, isoleucine and leucine obtained in 02 progenies (Table 3) were similar to those reported by RojasMolina et al. (2008) in QPM corn flour. In the same way, the significantly higher levels of aspartic and glutamic acid shown by opaque-2 genotypes in relation to white corn (Table 3 ) were coincident with other previous studies (Arruda, Da-Silva and Teixeira, 1978), since these amino acids are structural components of zein. Despite variations in the different amino acid contents of the kernels, the higher protein quality resulting from 02 mutation in maize is directly associated with an increase in lysine and tryptophan biosynthesis, as well as a change in the endosperm protein composition (Gayral et al., 2016; Ortiz-Martinez et al., 2017).

Lysine content showed a negative correlation with total protein content $(r=-0.54 ; P<0.05)$, as reported in other studies (Pereira et al., 2008; Cázares-Sánchez et al., 2015). Likewise, the negative correlation obtained between lysine and zein in this study in both crop years $(r=-0.69$ in 2012 and $r=-0.43$ in 2013; $P<0.05$ ) was coincident with other reports in which a higher lysine amount in o2 genotypes led to a reduction in total protein level and therefore in zeins (Landry et al., 2005; Gibbon and Larkins, 2005; Kriz, 2009). Previous research studies indicated a negative correlation between zein and lysine contents as well as between zein and tryptophan levels, because lysine and tryptophan in maize are directly related (Yau et al., 1999). In addition, the positive correlation obtained between lysine content and albumin fraction $(r=0.81 ; P<0.05)$ in the present study would indicate that the higher lysine content of 02 genotypes was probably due to a higher proportion of mainly albumin levels, in relation to the other non-zein fractions, as reported by Rojas-Molina et al. (2008) in nixtamalized QPM corn flours.

\section{Variance components}

The genetic variance showed the highest contribution to the total variability obtained in most of the grain characteristics analyzed in this study (Table 4). The lipids in corn kernel are controlled mainly by genetic factors and they are not much affected by the environment and agronomic practices (Arendt and Emanuele, 2013), which could be related to the high genetic variance shown by lipid content (Table 4). However, some studies demonstrated variations in grain lipid content in hybrids cultivated on different plant densities (Scott et al., 2006). A higher contribution of genetic variance was observed in starch content and the effects of crop year and interaction were lower and similar to each other (Table 4). Similar results were reported by Wei, Dai and Liu (2008) in relation to starch and lipid contents.

Similar contributions of the genetic variance and of crop year were obtained in protein content (Table 4). Wei et al. (2008) reported similar results in protein content between 10 inbred maize lines. On the other hand, Li et al. (2009) obtained low total genetic and additive variances among 14 corn lines indicating a marked environmental influence on this trait. In this study, the contribution of crop year in the protein content was higher than that of genotype $x$ year interaction (Table 4), probably due to the significant high maximum temperatures

Table 4. Relative contribution of genetic (GV), environmental (crop year) (EV) and genotype x year interaction (GxE) variances on the total variability in the studied traits from whole grain flour of opaque-2 maize genotypes

\begin{tabular}{|c|c|c|c|c|c|c|c|c|c|}
\hline & \multirow{3}{*}{ Starch } & \multirow{3}{*}{ Lipid } & \multirow{3}{*}{ Ash } & \multirow{3}{*}{ Protein } & \multicolumn{4}{|c|}{ Protein composition } & \multirow{3}{*}{ PD } \\
\hline & & & & & \multirow{2}{*}{ Lysine } & Zeins & \multicolumn{2}{|c|}{ Non-zeins } & \\
\hline & & & & & & 1) $Z+Z 2$ & $A L+G B$ & $\mathrm{G} 2+\mathrm{G} 3$ & \\
\hline GV (\%) & 67.1 & 88.9 & 75.1 & 51.0 & 97.3 & 92.0 & 64.2 & 82.7 & 86.1 \\
\hline EV (\%) & 15.3 & 2.7 & 18.8 & 45.1 & 1.7 & 3.3 & 32.4 & 10.6 & 2.0 \\
\hline $\mathrm{G} \times \mathrm{E}(\%)$ & 17.6 & 8.3 & 6.1 & 3.8 & 1.0 & 4.7 & 3.4 & 6.7 & 11.9 \\
\hline
\end{tabular}

1) $Z+Z 2$ = zeins; $A L+G B=$ albumins + globulins; $G 2+G 3$ = glutelins; $P D=$ in vitro protein digestibility. 
recorded during grain filling during the progenies cycle (Table 1).

The genetic variance showed the highest contribution to the total variability in zein content (Table 4), and the same behavior was observed in the non-zein fractions, since the changes in zeins alter the other protein fraction proportions in 02 mutant genotypes (Landry et al., 2005). The zein content in maize depends on the genotype due to strict control of spatial and temporal expression of the genes that encode them, regardless of culture conditions (Dolfini, Landoni, Tonelli, Bernard and Viotti, 1992; Landry et al., 2005). In the endosperm hardness of QPM germplasm, additive effects are more important than non-additive effects because of the 02 mutation genetic background (Dolfini et al., 1992), which is closely related to zein content since zeins contribute to endosperm hardness (Dombrink-Kurtzman and Bietz, 1993).

A high contribution of the genetic variance was observed on the in vitro protein digestibility. However, the effect of genotype $x$ year interaction was higher than the other protein composition traits (Table 4). Apart from the grain structural characteristics, cooking processes can influence the protein enzymatic digestibility (Duodu et al., 2002).

In the lysine content, the genetic variance contributed to almost all the obtained variability, while effects of crop year and interaction were practically negligible in relation to the genetic effect (Table 4). Other studies have demonstrated similar results (Wegary, Labuschagne and Vivek, 2011). Lysine content of corn kernel is determined mainly by the female parent, indicating an additive effect significantly higher than dominance variance on this trait (Tang et al., 2011).

\section{CONCLUSION}

A great variability in physical traits such as grain hardness and the flour chemical composition was found in the genetic materials. The variations of annual averages in centesimal composition show general trends in the proportional changes of the grain starch, protein, lipid and ash contents between generations. The variability in protein composition was related to the differences seen in zein and non-zein protein fractions between opaque-2 genotypes. Concomitantly, electrophoretic patterns of zein fraction evidenced differences between genotypes; this reflects variability in protein composition and in lysine content and results in a modification in the nutritional quality of grain protein. On the other hand, taking into account that o2 mutation produces a soft floury endosperm, which is agronomically unfavorable, in this study some genotypes presented better protein quality and remarkable grain hardness, as was observed in the P13 and P28 progenies.

The higher contribution of genetic variance obtained in zein and lysine contents indicates a marked dependence on genotype, despite the high crop year effect obtained in total protein content. This could indicate a strong additive component in total genetic variance in zein and lysine. However, experiments involving a larger number of environments and sample size are required to obtain a more substantial evidence of the genetic effects on these traits, as the contributions of crop year and genotype $x$ year interaction variances indicate environmental influence.

In vitro protein digestibility of opaque-2 kernels suggests that their structural characteristics, such as lower zein content, could result in a better protein digestibility, which would be relevant from a nutritional point of view given its high protein quality. However, studies based on protein bioavailability are required to obtain a more accurate nutritional evidence.

The differences found in the protein composition of opaque-2 genotypes would facilitate the identification of individual families with lower zein proportion and higher lysine content for their use in subsequent selection cycles. It would also enable researchers to continue improving and developing varieties with specific traits for production of processed food with higher nutritional quality.

\section{ACKNOWLEDGEMENTS}

The authors acknowledge Gabriela Díaz Cortéz for providing useful suggestions to improve the English language manuscript. The authors also acknowledge the Agencia Nacional de Promoción Científica y Tecnológica (ANPCyT, PICT 2012, N 1050), the Consejo Nacional de Investigaciones Científicas y Técnicas (CONICET, PIP 2012 Nº 11220110101051) and the Secretaría de Ciencia y Tecnología de la Universidad Nacional de Córdoba (SECyT - UNC, 05/G594) for financial support.

\section{REFERENCES}

AACC International (2010). Approved Methods of Analysis. 11th ed. Methods 08-01.01, 30-25.01, 4419.01, 46-12.01. Retrieved from: https://methods. aaccnet.org/about.aspx 
Acquaah, G. (2012). Principles of Plant Genetics and Breeding (2nd ed). Hoboken, USA: John Wiley \& Sons Ltd.

Alaiz, M., Navarro, J. L., Girón, J. and Vioque, E. (1992). Amino acid analysis by high performance chromatography alter derivatization with diethyl ethoxymethylenemalonate. Journal of Chromatography A, 591, 181-186.

AOAC International. (1999). Official Methods of Analysis of the Association (16th ed.) 5th Revision. (Method 994. 13). Gaithersburg, USA: AOAC International.

Arendt, E. K. and Emanuele, Z. (2013). Cereal grains for the food and beverage industries. Cambridge, UK: Elsevier.

Arruda, P., Da-Silva, W. J. and Teixeira, J. P. (1978). Protein and free amino acids in a high lysine maize double mutant. Phytochemistry, 197, 1217-1218.

Beckles, D. M. and Thitisaksakul, M. (2014). How environmental stress affects starch composition and functionality in cereal endosperm. Starch, 66, 58-71.

Cázares-Sánchez, E., Chávez-Servia, J. L., SalinasMoreno, Y., Castillo-González, F. y Ramírez-Vallejo, P. (2015). Variación en la composición del grano entre poblaciones de maíz (Zea mays L.) nativas de Yucatán, México. Agrociencia, 49, 15-30.

Corcuera, V., Salmoral, E., Kandus, M., Ferrero, V., y Salerno, J. (2013). Análisis proximal del grano de los maíces de uso especial. I. Contenido de proteína, almidón y aceite. En Asociación Argentina de Tecnólogos Alimentarios (Ed.), XIV Congreso Argentino de Ciencia y Tecnología de Alimentos. Rosario, Argentina: Asociación Argentina de Tecnólogos Alimentarios. ISBN: 978-987-22165-5-9.

Corcuera, V., Salmoral, E., Pennisi, M., Kandus, M. y Salerno, J. (2016). Análisis composicional cuanticualitativo de los macronutrientes del grano de híbridos de maíz con valor mejorado (VEC) desarrollados para la industria alimentaria argentina. Revista de Divulgación Técnica Agropecuaria, Agroindustrial y Ambiental Facultad de Ciencias Agrarias. UNLZ. 3 (2), 37-51.

Di Rienzo, J.A., Casanoves F., Balzarini M.G., Gonzalez L., Tablada M. y Robledo C.W. InfoStat (versión 2018) [Software de cómputo]. Córdoba, Argentina, Facultad de Ciencias Agropecuarias, Universidad Nacional de Córdoba, Argentina.

Di Rienzo, J. A., Macchiavelli, R. y Casanoves, F. (2017). Modelos Lineales Mixtos: Aplicaciones en InfoStat. Retrieved from: https://www.researchgate.net/ publication/283491350_Modelos_lineales_mixtos_ aplicaciones_en_InfoStat

Di Rienzo, J., Guzmán, A. and Casanoves, F. (2002). A multiple comparisons method based on the distribution of the root node distance of a binary tree. Journal of
Agricultural, Biological, and Environmental Statistics, 7, 1-14.

Dolfini, F. S., Landoni, M., Tonelli, C., Bernard, L. and Viotti, A. (1992). Spatial regulation in the expression of structural and regulatory storage protein genes in Zea mays endosperm. Genesis: Journal of Genetics and Development, 13, 264-276.

Dombrink-Kurtzman, M. A. and Bietz, J. A. (1993). Zein composition in hard and soft endosperm of maize. Cereal Chemistry, 70, 105-108.

Duodu, K. G., Nunes, A., Delgadillo, I., Parker, M. L., Mills, E. N., Belton, P. S. and Taylor, J. R. (2002). Effect of grain structure and cooking on sorghum and maize in vitro protein digestibility. Journal of Cereal Science, 35, 161-174.

Gayral, M., Gaillard, C., Bakan, B., Dalgalarrondo, M., Elmorjani, K., Delluc, C., Brunet, S., Linossier, L., Morel, M. H. and Marion, D. (2016). Transition from vitreous to floury endosperm in maize (Zea mays L.) kernels is related to protein and starch gradients. Journal of Cereal Science, 68, 148-154.

Gibbon, B. and Larkins, B. (2005). Molecular genetic approaches to developing quality protein maize. Trends in Genetics, 21, 227-233.

Gunaratna, N. S., Groote, H., Nestel, P., Pixley, K. V. and McCabe, G. P. (2010). A meta-analysis of communitybased studies on quality protein maize. Food Policy, 35, 202-210.

Habben, J. E., Kirleis, A.W. and Larkins, B.A. (1993). The origin of lysine containing proteins in opaque-2 maize endosperm. Plant Molecular Biology, 23, 825-838.

Hamaker, B. R., Kirleis, A. W., Butler, L. G., Axtell, J. D. and Mertz, E. T. (1987). Improving the in vitro protein digestibility of sorghum with reducing agents. Proceedings of the National Academy of Sciences of the United States of America, 84, 626-628.

Hamaker, B. R., Kirleis, A. W., Mertz, E. T. and Axtell, J. D. (1986). Effect of cooking on the protein profiles and in vitro digestibility of sorghum and maize. Journal of Agricultural and Food Chemistry, 34, 647-649.

Hoseney, C. R. (1994). Principles of Cereal Science and Technology (2nd ed). Minnesota, USA: AACC International.

Jia, M., Wu, H., Clay, K. L., Jung, R., Larkins, B. A. and Gibbon, B. C. (2013). Identification and characterization of lysine rich proteins and starch biosynthesis genes in the opaque-2 mutant by transcriptional and proteomic analysis. BMC Plant Biology, 13, 60-74.

Joshi, S., Lodha, M. L. and Mehta, S. L. (1980). Regulation of starch biosynthesis in normal and opaque-2 maize during endosperm development. Phytochemistry, 19, 2305-2309. 
Krivanek, A. F., Groote, H., Gunaratna, N. S., Diallo, A. O and Friesen, D. (2007). Breeding and disseminating quality protein maize (QPM) for Africa. African Journal of Biotechnology, 6, 312-324.

Kriz, A. L. (2009). Enhancement of amino acid availability in corn grain. In:T. Nagata, H. Lörz and J.H. Widholm (Eds.), Molecular genetic approaches to maize improvement, Biotechnology in Agriculture and Forestry Series (79-89). Heidelberg/Berlin, Germany: Springer. doi:10.1007/978-3-540-68922-5_7

Kutka, F. (2011). Open-Pollinated vs. Hybrid Maize Cultivars. Sustainability, 3, 1531-1554.

Landry, J., Damerval, C., Azevedo, R. and Sonia, D. (2005). Effect of the opaque and floury mutations on the accumulation of dry matter and protein fractions in maize endosperm. Plant Physiology and Biochemistry, 43, 549-556.

Landry, J., Delhaye, S. and Damerval, C. (2004). Protein distribution pattern in floury and vitreous endosperm of maize grain. Cereal Chemistry, 81, 153-158.

Li, H. C., Liu, Y. B., Cheng, R. X., Sun, X. Z., Wang, Y., Tang, J. H. and Liu, Z. H. (2009). Inheritance effect of protein content in maize kernels and its relation to yield. Acta Agronomica Sinica, 35, 755-760.

Magoja, J. L. and Nivio, A. A. (1982) High-quality protein maize with normal genotype: Inheritance of lysine content. Mendeliana, 56,110-111.

Magoja, J. L., Nivio, A. A. and Streitenberger, M. E. (1984). High-quality protein maize with normal genotype: lysine content of selected inbreds. Mendeliana, 58, 121-122.

Malumba, P., Vanderghem, C., Deroanne, C. and Béra, F. (2008). Influence of drying temperature on the solubility, the purity of isolates and the electrophoretic patterns of corn proteins. Food Chemistry, 111, 564572.

Mansilla, P. S., Nazar, M. C. and Pérez, G. T. (2017). Comparison of flour starch properties in half-sib families of opaque-2 maize (Zea mays L.) from Argentina. Cereal Chemistry, 94, 942-949.

Mendoza-Elos, M., Andrio-Enríquez, E., Juarez-Goiz, J. M., Mosqueda-Villagómez, C., Latournerie-Moreno, L., Castañón-Nájera, G., López-Benítez, A., y MorenoMartínez, E. (2006). Contenido de lisina y triptófano en genotipos de alta calidad proteica y normal. Universidad y Ciencia, México, 22, 153-162.

Mertz, E. T., Bates, L. S. and Nelson, O. E. (1964). Mutant gene that changes protein composition and increases lysine content of maize endosperm. Science, 145, 279-280.

Narváez-González, E. D., Figueroa-Cárdenas, J., Taba, S., Castaño-Tostado, E., Martínez-Peniche, R. A. and Rincón-Sánchez, F. (2006). Relationships between the microstructure, physical features, and chemical composition of different maize accessions from Latin America. Cereal Chemistry, 83, 595-604.

Ngaboyisonga, C., Njoroge, K., Kirubi, D. and Githiri, S. M. (2008). Effects of field conditions, low nitrogen and drought on genetic parameters of protein and tryptophan concentration in grain of quality protein maize. International Journal of Plant Production, 2, 137-152.

Ortiz-Martinez, M., Otero-Pappatheodorou, J. T., SernaSaldívar, S. O. and García-Lara, S. (2017). Antioxidant activity and characterization of protein fractions and hydrolysates from normal and quality protein maize kernels. Journal of Cereal Science, 76, 85-91.

Pereira, R. C., Davide, L. C., Pedrozo, C. A., Carneiro, N. P., Souza, I. R. and Paiva, E. (2008). Relationship between structural and biochemical characteristics and texture of corn grains. Genetics and Molecular Research, 7, 498-508.

Prasanna, B. M., Vasal, S. K., Kassahun, B. and Singh, N. N. (2001). Quality protein maize. Current Science, 81, 1308-1319.

Rodriguez-Nogales, J. M., Garcia, M. C. and Marina, M. L. (2006). High-performance liquid chromatography and capillary electrophoresis for the analysis of maize proteins. Journal of Separation Science, 29,197-210.

Rojas-Molina, I., Gutiérrez, E., Cortés-Acevedo, M. E., Falcón, A., Bressani, R., Rojas, A., Ibarra, C., PonsHernández, J. L., Guzmán-Maldonado, S. H., CornejoVillegas, A. and Rodríguez, M. E. (2008). Analysis of quality protein changes in nixtamalized QPM flours as a function of the steeping time. Cereal Chemistry, 85, 409-416.

Rossi, D. (2007). Evolución de los cultivares de maíz utilizados en la Argentina. Revista Agromensajes, Facultad de Ciencias Agrarias, Universidad Nacional de Rosario, 22, 3-11.

Salinas, M. Y., Bustos, F. y Gomez, J. H. (1992). Comparación de métodos para medir la dureza del maíz (Zea mays L.). Archivos Latinoamericanos de Nutrición, 42, 59-63.

Scott, M. P., Edwards, J. W., Bell, C. P., Schussler, J. R. and Smith, J. S. (2006). Grain composition and amino acid content in maize cultivars representing 80 years of commercial maize varieties. Maydica, 51, 417-423.

Serna-Saldivar, S. O. (2010). Cereal Grains: Properties, Processing, and Nutritional Attributes. CRC Press: Boca Raton, FL, 796 pp.

Sofi, P. A., Wani, S. A., Rather, A. G. and Wani, S. H. (2009). Quality protein maize (QPM): Genetic manipulation for the nutritional fortification of maize. Journal of Plant Breeding and Crop Science, 1(6), 244-253. 
Tang, J. H., Ji, H. Q., Liu, Y. B., Zhang, J., Tan, X., Hu, Y. M. and Liu, Z. H. (2011). Inheritance of lysine content in kernel and relationship between lysine content and yield in maize. Acta Agronomica Sinica, 37, 1585-1591.

Thitisaksakul, M., Jiménez, R. C., Arias, M. C. and Beckles, D. M. (2012). Effects of environmental factors on cereal starch biosynthesis and composition. Journal of Cereal Science, 56, 67-80.

Vera-Guzmán, A. M., Chávez-Servia, J. L. y CarrilloRodríguez, J. C. (2012). Proteína, lisina y triptófano en poblaciones nativas de maíz mixteco. Revista Fitotecnia Mexicana, 35, 7-13.

Vivek, B. S., Krivanek, A. F., Palacios-Rojas, N., TwumasiAfriyie, S. y Diallo, A. O. (2008). Mejoramiento de maíz con calidad de proteína (QPM): Protocolos para generar variedades QPM. México, D.F., México: CIMMYT.

Wall, J. S. and Bietz, J. A. (1987). Differences in corn endosperm proteins in developing seeds of normal and opaque-2 corn. Cereal Chemistry, 64, 275-280.

Wall, J. S. and Paulis, J. W. (1978). Corn and sorghum grain proteins. Advances in cereal science and technology, 3, 135-219.
Wang, X. L., Woo, Y. M., Kim, C. S. and Larkins, B. A. (2001). Quantitative trait locus mapping of loci influencing elongation factor 1 alpha content in maize endosperm. Plant Physiology. 125, 1271-1282.

Waterborg, J. H. (2002). The Lowry Method for Protein Quantitation. In: J. M. Walker (Ed.), The Protein Protocols Handbook (7-9). Totowa, USA: Humana Press Inc.

Wegary, D., Labuschagne, M. T. and Vivek, B. S. (2011). Protein quality and endosperm modification of quality protein maize (Zea mays L.) under two contrasting soil nitrogen environments. Field Crops Research, 121, 408-415.

Wei, L. M., Dai, J. R. and Liu, Z. X. (2008). Genetic effects of grain protein, starch and oil contents in maize. Science Agriculture Sinica, 41, 3845-3850. (In Chinese).

Yau, J. C., Bockholt, A. J., Smith, J. D., Rooney, L. W. and Waniska, R. D. (1999). Maize endosperm proteins that contribute to endosperm lysine content. Cereal Chemistry, 76, 668-672. 